\title{
Geocraft as a Means to Support the Development of Smart Cities, Getting the People of the Place Involved - Youth Included -
}

DOI: 10.12776/QIP.V21I1.784

\author{
Henk Scholten, Steven Fruijtier, Eduardo Dias, Sanne Hettinga, Mark \\ Opmeer, Willemijn S. van Leeuwen, Marianne Linde, Steven Bos, Rubio \\ Vaughan, Heidy van Kaam, Niels van Manen, Ceciel Fruijtier
}

Received: 9 September 2016 Accepted: 24 February 2017 Published: 30 April 2017

\begin{abstract}
Purpose: In this paper we present Geocraft, a Geo-ICT framework meant to provide the information needed to support the development of smart cities in an accessible and user-friendly way. We explored whether Geocraft could be an effective way to get the people of the place, especially youth, involved in geospatial issues.
\end{abstract}

Methodology/Approach: Geocraft is a virtual environment in which we import real geospatial data into the gaming environment of the popular computer game Minecraft ${ }^{1}$. In Geocraft, we can run real-time impact models to virtually simulate ánd visualise future developments and their implications, providing the user with relevant information during design processes. Geocraft is linked to Spatial Data Infrastructures (SDIs); data generated or added in Geocraft can upgrade existing databases and SDIs. In four use cases, Geocraft is used by children and high school students to address spatial planning challenges with the help of Geocraft.

Findings: Geocraft has an appropriate level of abstraction to effectively represent the real world. The use of Geocraft enhances insight in geospatial relations and can raise awareness and insights in a number of geospatial issues. Geocraft can be used to collect the ideas of citizens, in this case children, and engage them in urban planning issues to raise solutions that can reckon on public support. Geocraft can engage thousands of children working on the same geospatial project in the same online Geocraft world. Spatial scenarios designed in Geocraft can be effectively translated into a feasible spatial design and be

${ }^{1}$ Minecraft@ is a trademark of Mojang. Mojang is not involved in this research, nor sponsoring it. 
imported to the digital environment of professional designers. Moreover, Geocraft turned out to be a valuable educational tool to develop typical $21^{\text {th }}$ century skills: communicating, finding and evaluating information, creating and innovating, collaborating and problem solving.

We conclude that as an easy to use smart visualisation tool, in which everybody can build future scenarios, Geocraft can be used to get the people of the place involved with geospatial issues.

Research Limitation/implication: We present qualitative research results. In the next step, we will investigate how statistically significant the improvements in learning skills are.

Originality/Value of paper: This paper presents a new digital environment facilitating citizen participation and educational processes. We use actual spatial data to transform physical reality into a parallel and playable virtual version of that reality. Herein we can simulate spatial processes and support collaboration. By doing so, we can provide unique visualizations of complex processes, raising insights across the borders of disciplines in an user-friendly way.

Category: Research paper

Keywords: citizen participation; spatial planning; smart cities; Minecraft; citizen science

\section{INTRODUCTION - WHY RAISING THE REAL WORLD IN MINECRAFT?}

In the Manifesto for Cities (World Urban Campaign partners, 2012), the UN declared that the battle for a more sustainable future will be won or lost in cities. In the next few decades, nearly three-quarters of world's population will live in cities. More than 60 percent of the built environment needed to accommodate these new urban dwellers has yet to be built. How we plan, build, and manage our cities now will determine the outcome of our efforts to achieve a sustainable and harmonious development tomorrow.

\subsection{Smart cities and smart governance}

A "smart city" is a city well performing in 6 characteristics. These characteristics are built on the combination of a smart economy, smart mobility, a smart environment, smart people, smart living and smart governance (Lazaroiu and Roscia, 2012). Smart Governance is about using the latest technology to facilitate and support better planning and decision making. It is about improving democratic processes and transforming the ways that public services are delivered (Kourtit, Nijkamp and Scholten, 2015). It cherishes, taps and utilizes the full potential of the collected experience, knowledge, talents and ideas of citizens who should be enabled to interact and work on creating enhanced cities and a better society. 
Modern ICT technology offers local initiatives and urban policies many opportunities to cooperate and to take decisions collaboratively. In 2014, we (Lee, Dias and Scholten, 2014) have explored the notion of 'Geodesign thinking' whereby spatial technologies such as integrated 3D modelling, network analysis, spatial iteration modelling, visualisation tools and public participation are used to answer 'what if' questions to design alternatives on all kind of aspects (Steinitz, 2012). What we need as the next step in our exploration is a synergetic multidisciplinary approach, exchanging data and insights across the limits of disciplines. Moreover, we need all stakeholders to get involved, especially the people of the place.

The decisive role of the people of the place is emphasized a.o. by the UN-Habitat publication 'The City we Need' (2016). Surely the people of the place know the place the best; they have the highly valuable expertise and unique insights into local situations and possibilities. The daily urban activities of citizens contribute to the sustainable development of the city. Moreover, their engagement and participation are crucial for any successful plan (World Urban Campaign partners, 2016).

As we have entered the era of the Internet of Things, a growing wealth of sensor data has become available and interconnected (Van der Zee and Scholten, 2014). Digital technology evolves at an incredible speed. We think the main challenge lies in offering the available data - and the insights from data analysis - in a way end users can really work on building up smart cities in general and sustaining smart governance in particular.

So the question is: how to get the people of the place involved? We decided to address the children. Children are the adults of the future - the future inhabitants of the public space we design today. Moreover: through the children, the parents can be reached. By playing computer games, children train themselves extensively in geospatial skills. Minecraft is the second most sold video game (Tetris, released in 1984, still holds the first place). Minecraft has been sold worldwide more than 100 million times (Wikipedia, 2016). In The Netherlands, it is the most popular game among children in the age group 8 - 14 years (TwinQ, 2015). So we decided to import the real world in Minecraft. This georeferenced playable virtual version of the real world we call Geocraft ${ }^{2}$.

\subsection{Trends in spatial planning and citizen science}

To be able to understand the usefulness of Geocraft in the pursuit of sustainable and healthy cities, first of all we need to understand current planning systems and current policy themes. From various points of view, we stand at the threshold of a new era with respect to the development and governance of cities.

\footnotetext{
${ }^{2}$ Geocraft@ is a trademark of Geodan and GeoFort. It is not an official Minecraft-product; Geocraft is not certified by or associated with Mojang.
} 
Citizen initiatives in spatial development are on the rise (Boonstra, 2015). After decennia of top-down ruling and dominance of big players in the market, local initiatives blossom, shifting governance towards a more bottom-up approach. The advantages of large business estates and top-down planning systems are no longer valid. At the same time, lots of cities face the limits of expansion; for example in The Netherlands, we foster the limited green areas left. The focus has shifted towards intensifying, improving and transforming existing urban areas. This means that values of people of the place become more important.

A distinction is made between citizen involvement through participatory planning and spontaneous civic initiatives, which are hard to fit in with formal planning procedures (Boonstra, 2015). Both forms of activities of people of the place are in line with the ideas of active citizenship. Spatial planning strategies must bridge the gap between these informal processes and the formal framework of the planning system. Top down planning strategies are converted into more bottom up planning strategies.

Amsterdam, like many other cities, has created an informal platform to facilitate different types of initiatives ${ }^{3}$. Civic enterprises are stimulated in many different ways. Actual themes are circular economy, sustainable energy, healthy living and cycling, local care systems, urban food, multi-functionality of public space and reliability of sustainable mobility and transport networks. Citizen initiatives can be undertaken by residents, entrepreneurs, artists, etc., in loose and informal structures. For both participatory planning and citizen initiatives, Geocraft can be of added value at low costs. This requires:

- Access to open SDIs (e.g. National Data Warehouse PDOK (Bregt, et al., 2005), Datalab of Amsterdam (De Kleijn, et al., 2014));

- Data collection tools (using social media and sensing technology);

- Spatial Analysis tools for describing and analysing the impact of these initiatives and scenario's developed by local communities;

- Tools which translate citizen initiatives into more formal planning processes;

- Instruments for formal assessment procedures, like scenario design modelling instruments (e.g. LUMOS, which is developed under the coordination of the Dutch Environmental Assessment Agency, see Stillwell and Scholten, 2001; Koomen, Stilwell and Bakema, 2007), strategic environmental assessments, societal cost-benefit analyses and tools to calculate business cases for spatial investments.

${ }^{3}$ see a.o. https://dezwijger.nl/. 


\subsection{Scheme of this paper}

With Geocraft, we created a Geo-ICT framework based on the principle of Spatial Data Infrastructures (SDIs) to collect, visualise, analyse, design and share spatial scenarios in order to support smart governance. In section 2, Materials and Method, we describe how we did this and what is needed to maintain such a virtual environment.

Through internet technology, we can invite all citizens to join in, share their ideas and contribute to the design of future spatial scenarios. To investigate whether this is feasible, we started with four use cases wherein children address real world spatial planning challenges. These use cases are described in section 3 . In section 4 we discuss the results. Next, we mention the power of serious gaming in Geocraft in part 5. We finish with our conclusions in section 6.

\section{MATERIALS AND METHOD}

In the next paragraphs, we describe what techniques we developed and used to perform the research we present in this paper. The technique and software of Geocraft are developed by Geodan ${ }^{4}$, the use cases are planned and carried out by scientific researchers of the SPINlab ${ }^{5}$ and the staff members of the GeoFort ${ }^{6}$.

\subsection{Geocraft - the real world in Minecraft}

To facilitate children to play, work and design in the-real-world-in-Minecraft, we first had to import real geospatial data in Minecraft. A Minecraft world is a voxel based 3D environment made up of blocks of $1 \mathrm{~m}^{3}$. Every block represents a certain Minecraft material, e.g. wool, brickstone and water. Some of these materials can be detailed more e.g. to define colour or type of bricks. A group of $16 \times 16 \times 16$ of these blocks is called a chunk. The chunks of a $2 \mathrm{D}$ area of $512 \times 512$ blocks are stored in a region file. A Minecraft world consists of one or more of these region files depending on the size of the world.

In Geocraft, we can create worlds ranging in size from a neighborhood to the complete Netherlands (comprising over 1,000 billion blocks). Basically, all 2D and $3 \mathrm{D}$ geospatial data can be visualised. Different datasets of the same location can be added up, resulting in a more and more enriched view. This is illustrated by subsequent views on Bourtange, a fortified city at the north-eastern border of The Netherlands, see Fig. 1.

Potentially, all geospatial data of a specific geographical area can be added, including real-time sensor information from the Internet of Things. We can visualise data from different sources superimposed on each other. Not only

\footnotetext{
${ }^{4}$ Since 1985 , Geodan is one of the leading Geo-ICT companies in Europe. http://www.geodan.com.

${ }^{5}$ Spatial Information Laboratory, Faculty of Economics, Vrije Universiteit Amsterdam, The Netherlands. http://spinlab.vu.nl/.

${ }^{6}$ GeoFort is an educational attraction in the field of cartography and navigation. http://www.geofort.nl.
} 
concrete structures can be depicted, but also features like the amount of air pollution, traffic capacity, noise disturbance, energy labels, energy use and supply, flood risk, etc. The results of impact models can be superimposed on topographical data, 2D data can be combined with 3D data, etc. This results in an inventive representation of the city, visualizing the specific aspects of the city you want to analyse or display (see Fig. 2).
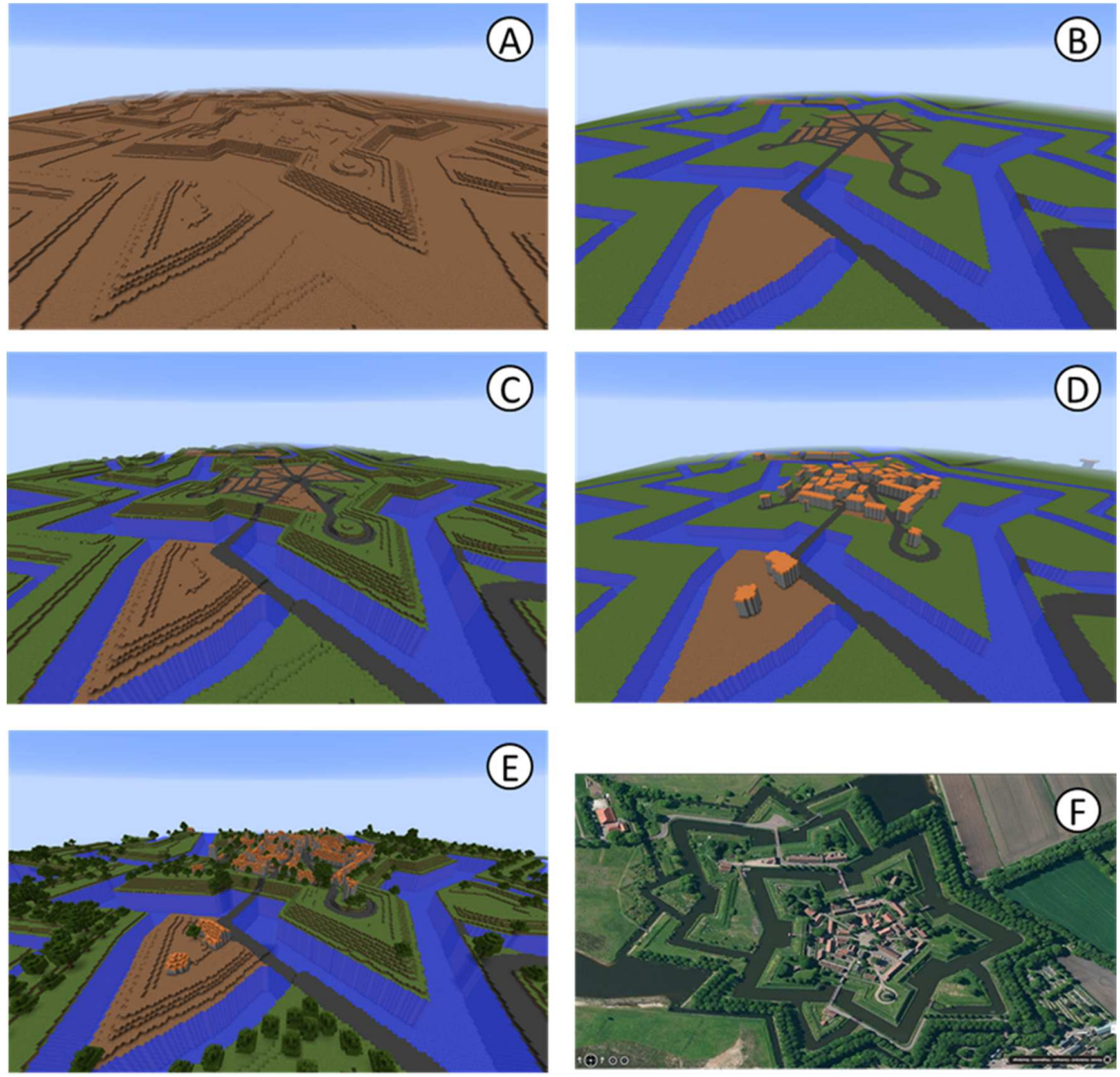

Figure 1 - Subsequent views of Bourtange, The Netherland; A: Surface Height transformed to Geocraf;. B: Topographic data transformed to Geocraft; C: Surface height and topographical data combined; D: Topographical data and $2 D$ building data combined; the building height is averaged; $E: 2 D$ data (tree location, building footprints, topographical data) combined with $3 D$ data (for surface height and buildings); F: Aerial photograph 


\subsection{SDI connected - possibility to provide real-time information during design processes and to export data to other SDIs}

Geocraft is connected to spatial data infrastructures (SDIs). Lots of organisations and governments use SDIs; in The Netherlands, there is a national spatial data infrastructure (Grus, et al., 2009), which is maintained by the Dutch government. Many local governments developed their own SDI on top of that. For example Datalab Amsterdam maintains many open datasets and explores new applications for data which is collected by different stakeholders in this city. Geocraft can connect to these existing data and visualise them in the virtual world of Minecraft. Potentially, all geospatial data of a specific geographical area can be added to Geocraft, forming a 3D database of that area capable of visualising data from different sources superimposed on each other. Different geospatial data can be visualised by choice.

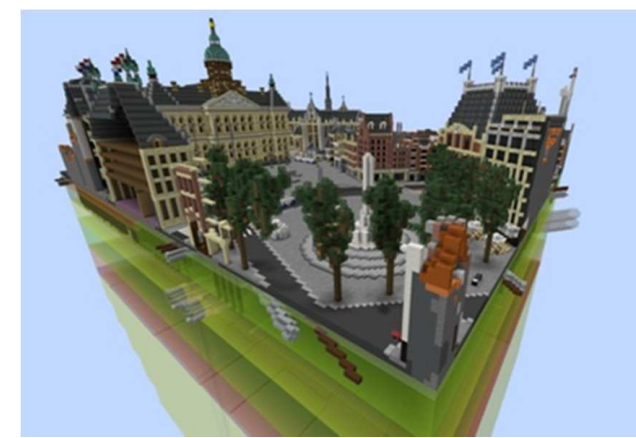

A

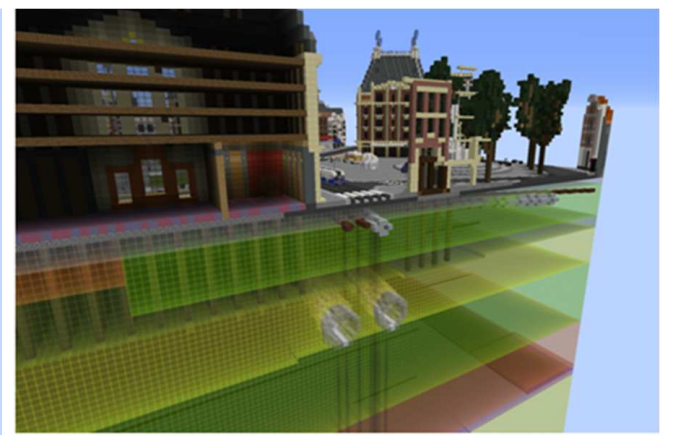

$B$

Figure 2 - Dam Square in Geocraft (Amsterdam, The Netherlands), including the underlying stratigraphy; Amsterdam is build on Holocene and Pleistocene sediments, basically alternating layers of sand (yellow), clay (green) and peat (brown); B shows a detail of A, revealing the piles whereon the buildings are build to be supported by the so-called first sand layer; In addition, this view shows the sewerage system, service pipes and the underground tubes; All cubes in Geocraft measure 1 to 1 meter

Geocraft is a truly interactive smart world. You can integrate your own data, for example, models and plug-ins in Geocraft that can provide instant information during design processes. For example, we can use the wind turbine planner (Dias, 2016) developed by Geodan (Rafiee, et al., submitted). When placing a specific type of wind turbine in the virtual environment of Geocraft, the wind turbine planner provides instantly visualised information about the area suffering of noise disturbance, indicated in different noise levels depending on the distance to the wind turbine and the surroundings (see Fig. 3). You see exactly which locations in the area are affected in what extend. At the same time, you can get information on other relevant aspects. For example the costs of this specific kind of wind turbine, whether this wind turbine is suited for this specific location (e.g. current legislation), how much energy this wind turbine is expected to generate, 
as well as the energy demand of the region. This way, impact analyses can provide results and relevant information during design processes as we illustrate in use case 3: Transition towards sustainable energy in Zaandam (see section 3.2.2).

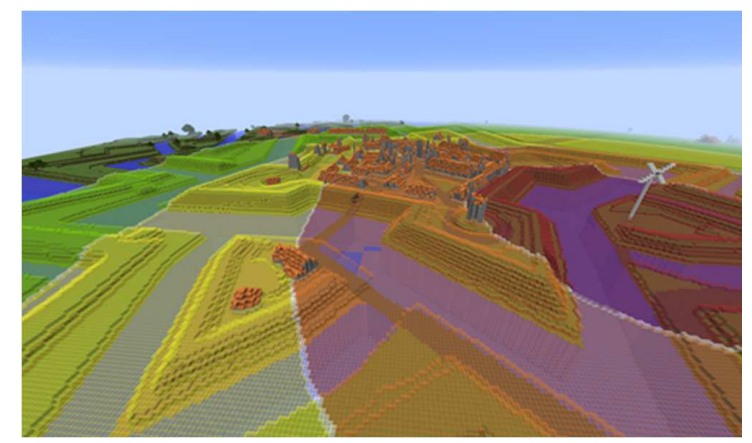

Figure 3 - The area suffering of noise disturbance after placing a specific kind of wind turbine; The purple area is most affected. Via pink and yellow zones the nuisance decreases towards the green area (Bourtange, $N L$ )

Data generated in Geocraft can be exported to other SDI based applications. That can offer interesting opportunities: the intuitive user interface of Minecraft enables non-experienced designers to design spatial scenarios that subsequently can be exported to more specialized 3D virtual environments like those of professional designers (see use case Designing the public space of Zeeburgereiland, section 3.2.1). In addition, the user of Geocraft can select a specific type of data that revealed to be of significant relevance to a certain process and export these to another more specialized SDI based environment. For example to run more sophisticated models and more detailed impact analyses than the ones at the moment available in Geocraft.

\subsection{The creation of a Geocraft world}

In table 1 , we provide an overview of the input data we used so far. We use a spatial-occupancy enumeration to convert this data to data that can be imported into the virtual environment of the popular Minecraft game. Spatial-occupancy enumeration is a special case of cell decomposition in which solids (in this case buildings and other spatial elements) are decomposed into identical cells arranged in a fixed, regular grid. These cells are often called voxels (volume elements), in analogy to pixels (Foley, et al., 1990).

The regular grid from Geocraft is north-south east-west oriented. This means that topographical elements (for example buildings) with an oblique orientation towards this grid (e.g. SW-NE) appear with 'jagged vertical surfaces' (see Fig. 4), whereas topographical elements with more or less north-south or east-west orientations appear flat, more similar to the way they look like in reality. 
Table 1 - Examples of geospatial data that can be imported in Geocraft

\begin{tabular}{|c|c|c|}
\hline \multirow[t]{2}{*}{ Ground level data } & \multicolumn{2}{|c|}{ Nation-wide point clouds (like AHN2 in The Netherlands) } \\
\hline & \multicolumn{2}{|c|}{ DEM (Digital Elevation Model) } \\
\hline \multirow[t]{2}{*}{ 2D topographic data } & \multicolumn{2}{|c|}{ Distribution of land versus water, infrastructural elements like roads, houses, etc. } \\
\hline & \multicolumn{2}{|c|}{$\begin{array}{l}\text { Landscape elements like trees or houses (like BAG data for buildings in The } \\
\text { Netherlands) }\end{array}$} \\
\hline \multirow[t]{4}{*}{ 3D data } & \multicolumn{2}{|c|}{ 3D data models like Collada, BIM } \\
\hline & \multicolumn{2}{|c|}{ Elements built by children, citizens or professional designers. } \\
\hline & \multirow[t]{2}{*}{$\begin{array}{l}\text { 3D subsurface } \\
\text { data }\end{array}$} & $\begin{array}{l}\text { A voxel representation of subsurface data (like Geotop in The } \\
\text { Netherlands) }\end{array}$ \\
\hline & & $\begin{array}{l}\text { Underground infrastructure; e.g. tunnel tubes, piles, pipelines, } \\
\text { wires, etc. }\end{array}$ \\
\hline $\begin{array}{l}\text { 2D or 3D results } \\
\text { from impact models }\end{array}$ & \multicolumn{2}{|c|}{$\begin{array}{l}\text { For example the area suffering noise disturbance after placing a wind turbine, or } \\
\text { the amount of energy saved after furnishing houses with double-glass. }\end{array}$} \\
\hline
\end{tabular}

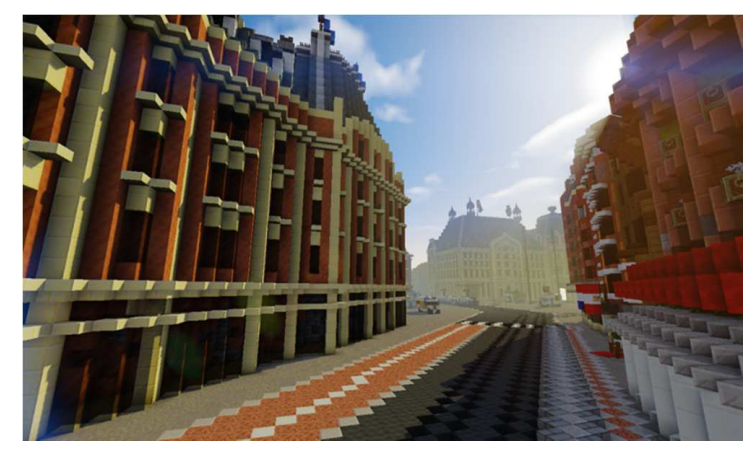

Figure 4-As a consequence of its SW-NE orientation, the surfaces of the buildings and the lines on the above street look jagged; the reality is represented well enough to be recognized by the people of the place (Dambrak, Amsterdam, NL)

Subsequently, we generate tiles according to the Minecraft scheme and map these raster files to the Geocraft region tiles. The first step, creating all needed raster files, only takes a few days on a single computer, even for a Geocraft world comprising the whole of The Netherlands. For the second step, the generation of the Geocraft region tiles, much more computer power is needed. For example: on a 4 core CPU machine, the creation of all region tiles of The Netherlands in Geocraft would require more than 100 days. However, this part of the process is suitable for parallel computing. 
To create The Netherlands in Geocraft, per region file a distinctive set of 4 input raster files (building height, surface height, trees and land use) is used. This allows the processes to be executed independently of each other. In a cloud based parallel computing environment, the conversion of all raster files into Geocraft region files can be executed in less than a day depending on the amount of cores allocated to the process. We deployed this process in the Microsoft Azure Batch platform, see Fig. 5. We describe the procedures in more detail in our paper "The Netherlands in Minecraft - Methodology and usage" (forthcoming).

The Netherlands are approx. 300x200 km in size. On a scale of 1 meter is 1 block this results in a Geocraft world of approx. 300,000x200,000 blocks in size or 60 billion square blocks. As every Minecraft world is divided into region files of $512 \times 512$ blocks, The Netherlands will consist of 586x391 region files or 229.126 Geocraft region files. Each Geocraft region file is approx. $4 \mathrm{MB}$ in size. The Netherlands in Geocraft will therefore be approx. 900 GB.

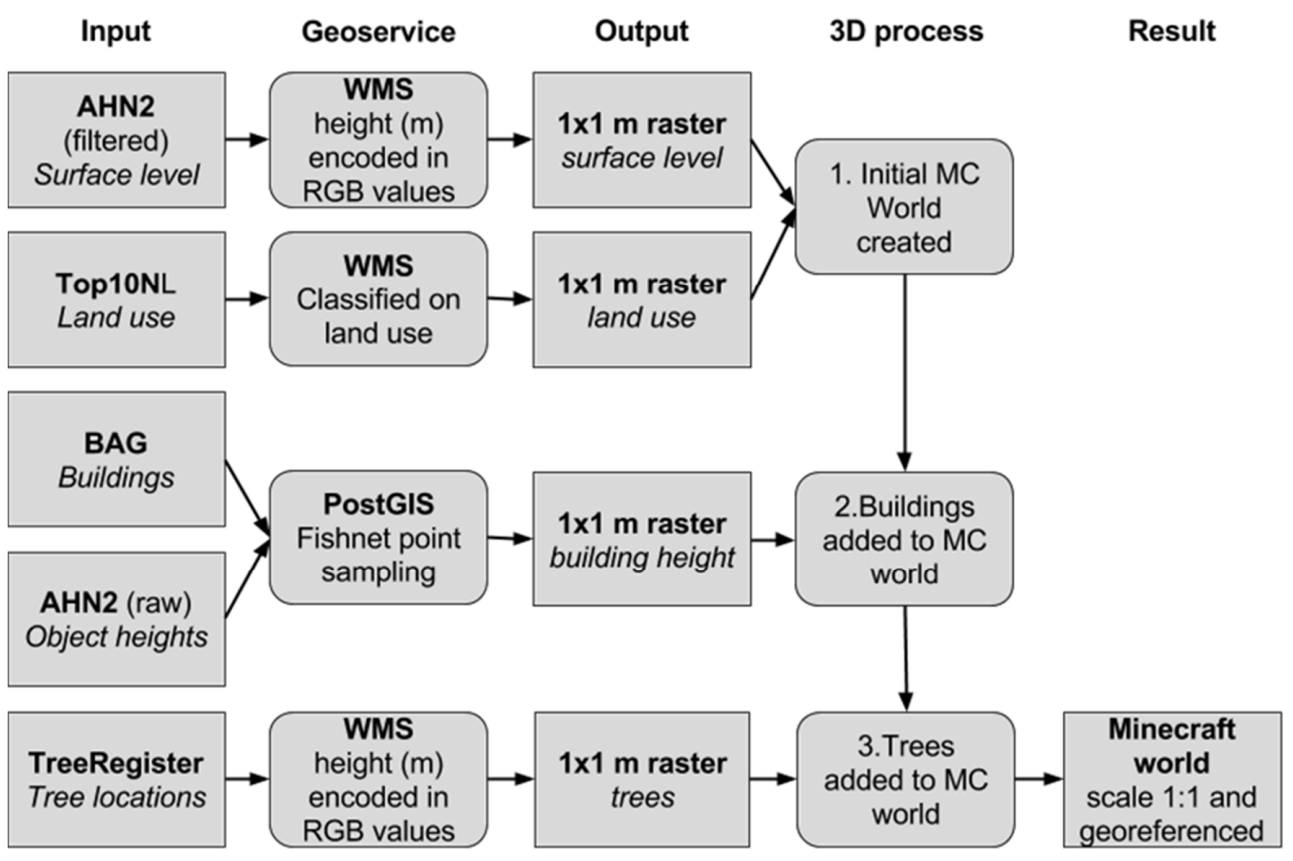

Figure 5 - From geospatial data to Geocraft world

The standard Minecraft server software offers little possibilities for managing the Minecraft worlds. Therefore, almost all Minecraft servers use modded Minecraft server software called Spigot. Spigot allows additional functionality and management options through plug-ins. Geodan developed plug-ins to add specific functionalities to Geocraft. We focussed on the connection with existing (spatial) data and services. An example is geocoding service used in GeoCraftNL. It allows people to teleport to a given address instead of entering coordinates. The geocoding plug-in takes the entered address and uses a web service from the GeodanMaps cloud environment to return the location of the 
address. Another plug-in calculates the energy efficiency of projects built in Geocraft and compares these to the actual local energy consumption. Another plug-in tracks and traces people real-time and shows their location in Minecraft.

\subsection{Hosting a Geocraft world}

Using a local copy of a Geocraft world, no hosting is needed. The single-player mode of Minecraft is dependent on data stored locally on your computer. This can be useful, for example when you add a 3D model and want to check whether it is loaded correctly before making the world available to other users. As soon as you want to share a Geocraft world with others, you use the Minecraft multiplayer mode and have to connect to the Minecraft server where this specific Geocraft world is hosted.

An example of a Minecraft server is the GeoCraftNL server, where people smarten up the basic contour lines of The-Netherlands-in-Minecraft by adding more detail and colour to mirror the real world, as described in paragraph 2.5. This server can be connected to through the address geocraft.nl. In principle, there is no limit to the amount of users you can give access to a Geocraft world, though there is a limit on the number of simultaneous users depending on the server configuration.

Another example of a Minecraft server is the one offered by the SPINlab of the Vrije Universiteit of Amsterdam to provide secondary schools (VWO level) with serious Geocraft games, addressing a variety of geospatial issues (see use cases). Setting up a server involves installing the Minecraft server software. The software can either be deployed on own servers or be hosted by a provider.

\section{USE CASES}

After importing the real world in Minecraft, we followed two pathways to introduce Geocraft to the Dutch children. Our partner GeoFort organized a nation-wide contest for Dutch children (see section 3.1), in an open Geocraft environment, that was accessible via the internet. Next, we offered Geocraft to high schools in a closed computer environment to enhance their education in spatial and geographical awareness ${ }^{7}$. We defined specific spatial issues and started 3 different high school projects wherein high school students address real world spatial planning challenges:

\footnotetext{
7 The Vrije Universiteit Amsterdam (VUA) is one of the first universities that took a structural approach to determine how spatial methods and skills for informed spatial reasoning can be provided in the best possible way (since 1990, the VUA has a chair in Spatial Information Science). The VUA has a record in providing innovative education support to high schools in order to enhance the spatial insight of high school students and to raise awareness and insights in geospatial issues. Since 2004, we are involved with EduGIS - the SDI for educational purposes offering a.o. over 500 maps of The Netherlands, Europe and the world. Yearly, over 75,000 children make use of this platform. As a result, we have a strong liaison with several high schools (Van der Schee and Scholten, 2009).
} 
- Designing the public space of Zeeburgereiland (see section 3.2.1);

- Towards more renewable energy and energy saving in Zaandam (see section 3.2.2);

- Future water management and land use of the Markermeer (see section 3.2.3).

Table 2 - Objectives of the use cases

\begin{tabular}{|l|l|}
\hline Use case & Objective \\
\hline The Netherlands in & $>\begin{array}{l}\text { Test whether the Minecraft level of abstraction allows for a realistic, } \\
\text { recognizable representation of the real world. }\end{array}$ \\
& $>\begin{array}{l}\text { Test whether Geocraft can support thousands of users via the internet. } \\
\text { Test whether it is possible to generate an organisational infrastructure } \\
\text { supporting a Geocraft community that contributes to a common geospatial } \\
\text { objective. }\end{array}$ \\
\hline $\begin{array}{l}\text { Designing the public } \\
\text { space of }\end{array}$ & $>\begin{array}{l}\text { Test whether non-Minecraft users can intuitively use Geocraft. } \\
\text { Zeeburgereiland } \\
\text { Test whether a spatial design created in Geocraft can result in a feasible } \\
\text { design for urban development. }\end{array}$ \\
\hline $\begin{array}{l}\text { Transition towards } \\
\text { sustainable energy in } \\
\text { Zaandam }\end{array}$ & $>\begin{array}{l}\text { Test whether a geospatial scenario build in Geocraft can contribute to } \\
\text { citizen participation processes. }\end{array}$ \\
& $>\begin{array}{l}\text { Test the added value of Geocraft for education on geospatial issues. } \\
\text { Test wher model generated input in Geocraft during designing raises an } \\
\text { beforehand. } \\
\text { Test whether model generated input in Geocraft raises understanding in the } \\
\text { multi-criteria analysis. }\end{array}$ \\
& $>\begin{array}{l}\text { Test whether Geocraft can be a useful tool to contribute to a multi- } \\
\text { stakeholder decision-making process. }\end{array}$ \\
\hline $\begin{array}{l}\text { Water management } \\
\text { and land use } \\
\text { Markermeer }\end{array}$ & $>\begin{array}{l}\text { Test the added value of Geocraft for education on geospatial issues. } \\
\text { Test the influence on team cooperation. } \\
\text { Test the impact on the quality of the proposed solutions compared to } \\
\text { working "the old way". } \\
\text { Test whether Geocraft users can incorporate insights of experts. }\end{array}$ \\
\hline
\end{tabular}

\subsection{The Netherlands in Minecraft - thousands of children enhancing the virtual representation of The Netherlands}

The educational attraction GeoFort organized a nation-wide contest for Dutch children which was announced on the national youth news channel (GeoCraft.NL, 2016a). Every Minecraft player can join the Geocraft.NL server online (GeoCraft.NL, 2016b). Geocraft players can find their way in the Geocraft.NL world by plug-ins made by Geodan and GeoFort: all the larger cities, towns and villages can be 'warped' by entering /WARP followed by the name of the place. The children are challenged to make The-Netherlands-inMinecraft look as realistic as possible. The results were stunning, see Fig. 6 and GeoCraft.NL (2016c). 

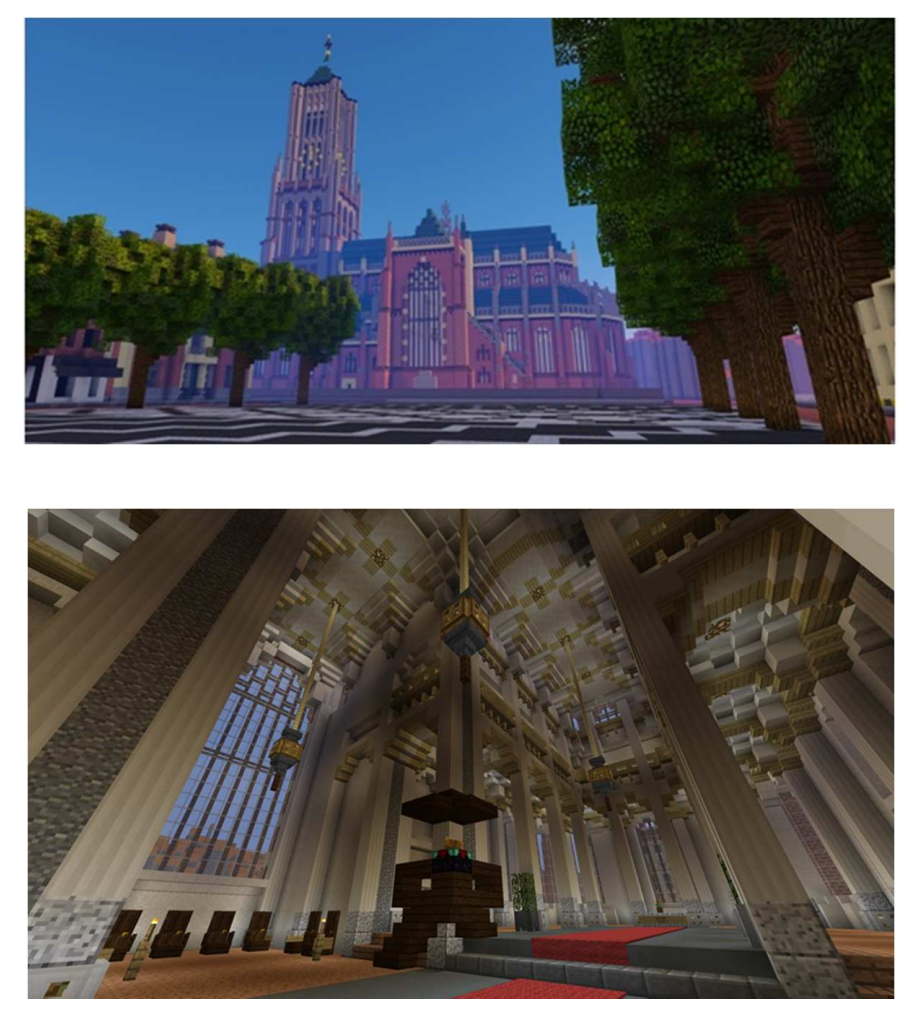

Figure 6 - The Eusebius church in Arnhem (The Netherlands), a marvellous example of Gothic architecture, very well represented in Geocraft

Over 20,000 Minecraft players have been building churches, fortresses, residences, schools, railway stations, hotels, shopping centers, town squares, etcetera.

\subsubsection{The dawning of a virtual society}

To make The-Netherlands-in-Minecraft look as realistic as possible, the Minecraft players had to turn the grey topographic elements imported from the topographical databases (e.g. buildings, traffic infrastructure, street furniture, etc.) into a realistic impression of the real world, using the Minecraft building blocks material, see Fig. 7. A description of the available tools in Minecraft to develop and create cities can be found in Kearney (2015).

On Geocraft.NL, collaboration and joint projects emerged spontaneously. Children communicate via the chat and initiate collective building projects, for example to finish the Dom Tower in Utrecht. The people of Vreeland joined efforts to add architectonic details to their town. The centre of Amsterdam is being collaboratively build by a group Minecraft players. 


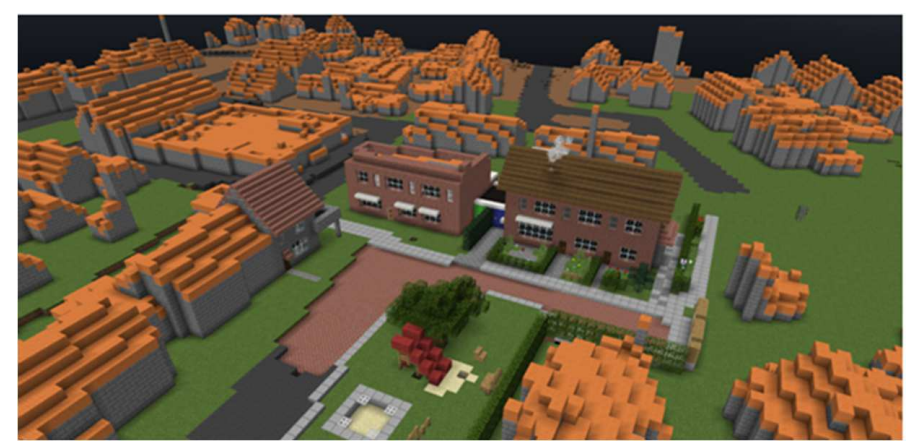

Figure 7 - Typical residential area, The Netherlands. Children enhanced the appearance of their own houses to make them look as realistic as possible (see in the middle of the depicted area); the grey buildings with orange roofs are how the data in Geocraft is offered; these residences are still waiting to get a more realistic appearance

The-Netherlands-in-Minecraft comprises over 1,000 billion blocks; it took some effort to oversee and regulate what the kids were doing. Initially, TheNetherlands-in-Minecraft were more or less immediately destroyed at the day of release. Volcanic flows emerged everywhere and many phallus symbols were raised. As in the real society, this virtual society needs regulations and administrative leadership.

\subsubsection{The call for regulations and enforcement}

Several measures had to be taken. First of all, The Netherlands had to be reloaded in Geocraft. Secondly, GeoFort developed a plug-in to register all Minecraft players; children who want to build in this Geocraft world have to register themselves as a GeoCitizen. A GeoCadastre and a hierarchic structure were established. The officials of the GeoFort themselves, maintaining and regulating this Geocraft world, have the highest ranks: 'Son of the King'. Adults spontaneously offering technical support and assistance are appointed 'Representatives'. All other officials are Minecraft playing children, who can apply for the job. GeoMayors give GeoCitizens rights to build on a limited area. GeoCommissionars of the King supervise Geomayors and have special building permits.

This hierarchic system worked for some time, but when some children started to berate one another, and others started to destroy buildings, it became clear that a penalty policy was needed. These rules are now clearly communicated to every GeoCitizen. Transgressing the rules, one might be muted, kicked or even banned. The Bijlmer Bajes (the jail of Amsterdam) was equipped to house delinquents spending their ban time.

\subsubsection{Crowd sourced in-game management}

In a year time, over 20,000 Minecraft players registered as GeoCitizen. GeoFort succeeded in establishing a partly crowded sourced in-game management, made 
out of teenagers who successfully applied to the job of GeoMayor or GeoCommissionar. Now these voluntary officials fulfil over 650 positions, familiarizing GeoGuests and newborn GeoCitizens with the rules and possibilities of Geocraft.NL. They answer questions, explane how to do things and serve out building plots to newborn GeoCitizens.

Besides these daily active volunteers, a couple of GeoFort workers deal with the administration and server management of Geocraft.NL on a day to day basis. Occasionally, GeoFort has to upscale its support and maintenance capacity, to deal with the growing numbers of visitors and actors in this virtual society.

\subsubsection{An immersive experience by using the Oculus Rift}

In 2016, GeoFort organised several Geocraft.NL events, inviting the GeoCitizens to meet in real life. On such occasions, hundreds of Minecraft players game together. On one such occasion, the children could visit Geocraft.NL with the Oculus Rift for an immersive 3D experience. If not seated the children (and adults) tried to walk as if they were in a real city. The immersive experience of the oculus rift gave an immediate understanding of the dimensions. The Minecraft blocks were actually perceived as blocks of 1x1x1 meter and buildings looked as big as in real-life, see Fig. 8.
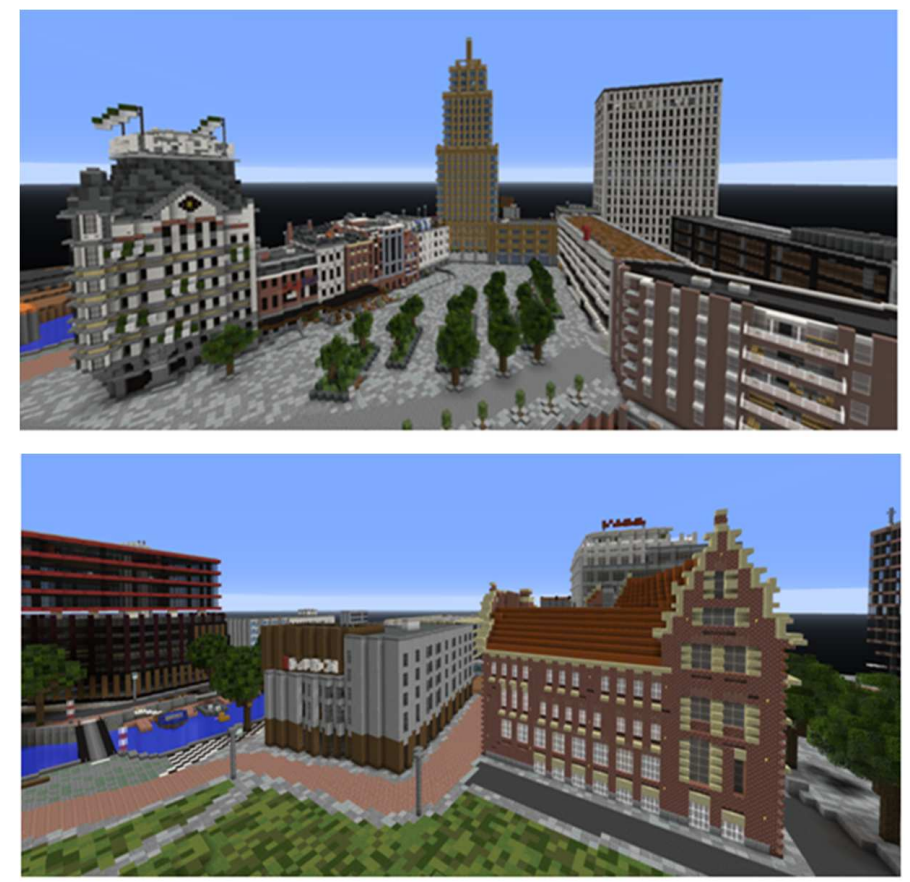

Figure 8-Different building styles are well represented (above: Gelderseplein, below: Vissteeg, both in Rotterdam, the Netherlands)

The visitors immediately recognized familiar places like their own neighbourhood, see Fig. 9. The immersion and sense of dimensions improved the 
orientation capabilities of the children. They better understood where they were and how to navigate to familiar places like home. Being immersed in Geocraft using the Oculus Rift, the children started to discuss things with each other like they were meeting in real life instead of in a virtual world (normally, children in Geocraft communicate via the in-game chat or chat services like Discord).

The challenge continues: GeoCitizens are invited to take screenshots of the buildings they are most proud of and send these to GeoFort. Weekly, GeoFort selects 'the building of the week'. Every day, The-Netherlands-in-Minecraft resembles reality more and more.

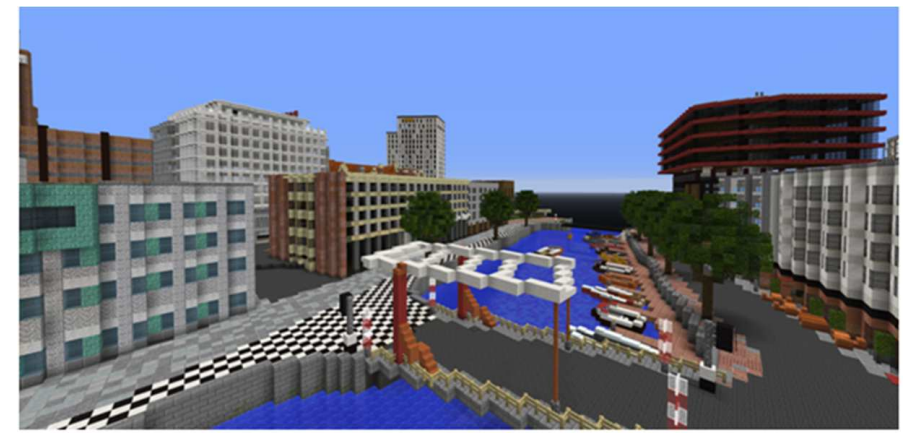

Figure 9 - People recognize immediately their own neighbourhood in Geocraft (Wijnhaven, Rotterdam, the Netherlands)

\subsection{High school projects using Geocraft to address specific geospatial issues in a closed computer environment}

We live in a three-dimensional world and lots of processes have a 3D component. We propose that these processes can be better studied and understood in a $3 \mathrm{D}$ environment. For the high school projects different servers were set up, hosting the study area. Every group worked on one of these servers in its own Geocraft world. The servers were unavailable for external Geocraft players or other groups within the school.

\subsubsection{Designing the public space around IJburg high school on Zeeburgereiland}

In Amsterdam, a former industrial area at the border of the city, Zeeburgereiland, is being redeveloped to form a lively residential area with space for sports, shopping, education etcetera. Four times a year, meet-ups are being organized to bring together different stakeholders, among which residents, entrepreneurs, and city officials, to discuss the development of this area (Pakhuis de Zwijger, 2016). At such a meeting the idea was born to use Geocraft to give the children a voice to express their wishes and ideas about the spatial design of the surroundings of the newly build IJburg high school. After all, they are the users of this place ${ }^{8}$.

\footnotetext{
${ }^{8}$ This project was initiated and facilitated by consultancy agency 'BuurtPerspectief' and the SPINlab of the Vrije Universiteit Amsterdam.
} 
The students already knew Minecraft or learned on the job. The students were divided into design teams to redesign the space around their school. They worked 4 sessions of 2 hours, one session per week. Each team got a simple instruction: change the current world into one you like! (Buurtperspectief, 2015a).
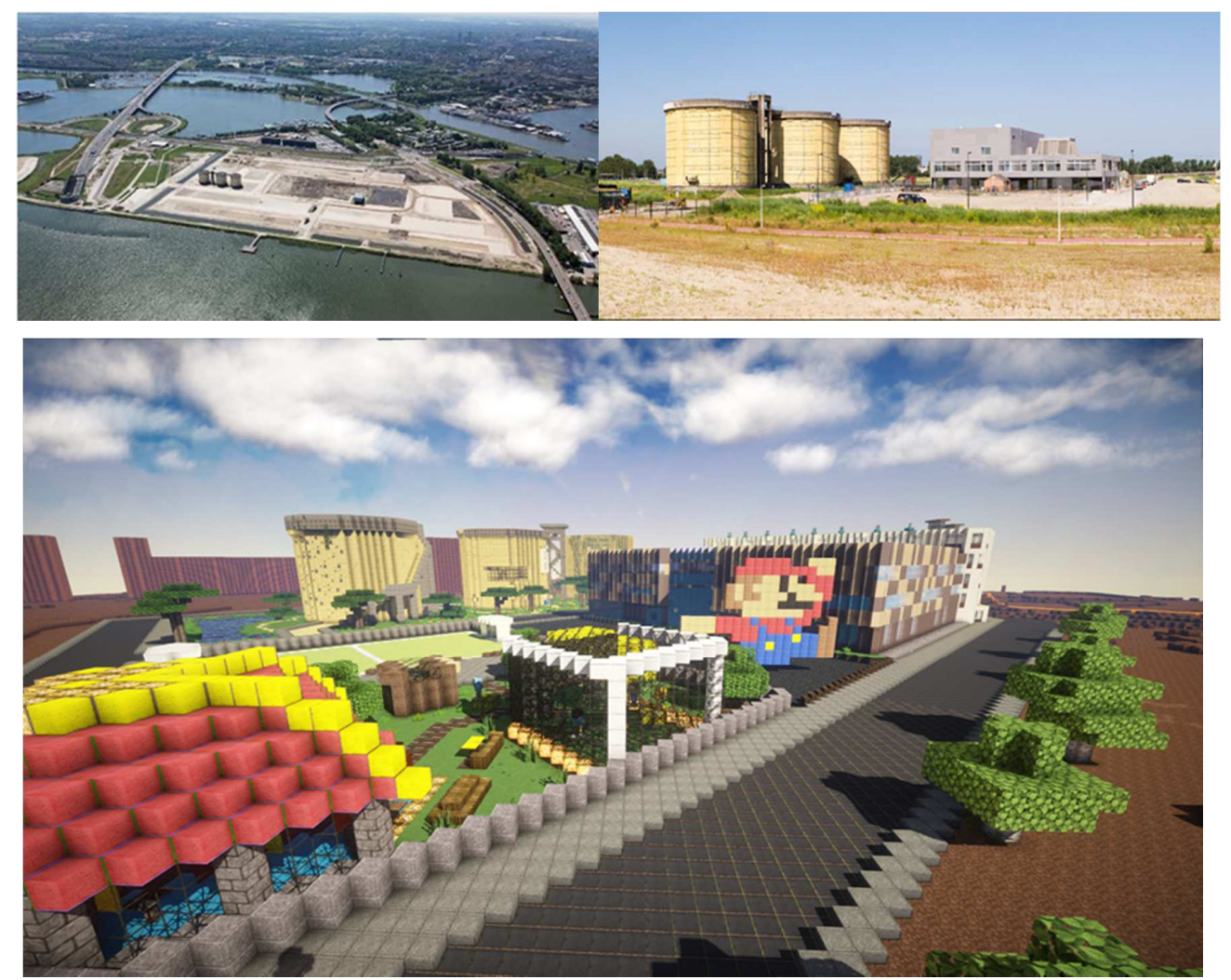

Figure 10 - Redevelopment site Zeeburgereiland, Amsterdam, The Netherlands; The IJburg high school is already in use, surrounded by wasteland and industrial remains; The students made a spatial planning design in Geocraft

Based on the input from the design teams, a professional urban planner amalgamated the different ideas of the students into one, feasible design, see Fig. 10 and Buurtperspectief (2015b). Not all objects created made it to the final design; explicit erotic street art and statues were not incorporated in the final design, or when several overlapping ideas were present (each group had a library) only one was picked.

This project adequately collected and inventoried the students' needs and wishes as users of the space, which were subsequently presented to the stakeholder meet-up. Using Geocraft, the students participated actively and were enabled to express definite wishes within the actual available space (such as the desired size of a football field, the preferred location of a skate park, etc.). This way, they 
provided distinct input for the professional urban planner. The final design met the students' wishes, including a playground for kids, pop-up stores, leisure and places to meet, in- \& outdoor activities. The students recognized the planner's design as their own design and would definitely support its realisation. At the moment of writing, the concrete realisation of parts of this design is being planned.

\subsubsection{Transition towards sustainable energy in Zaandam}

Worldwide we strive for energy saving and a transition towards renewable energy (European Union, 2009; SER, 2013). In Geocraft, we developed a serious game challenging the students of the Zaanlands Lyceum to come up with the best solution for their own neighbourhood. In Geocraft, they had to design a future scenario in order to realize the most energy saving and the most renewable energy, considering both the costs, the amount of $\mathrm{CO} 2$ reduction, and the resulting energy supply in $\mathrm{kWh} / \mathrm{m}^{3}$. Hereto, they could take three measures. Geodan developed dedicated plugins so that for each measure, models in Geocraft calculated costs and benefits:

- Raise wind turbines, see Fig. 11. The higher the wind turbine, the more energy is generated. However, higher wind turbines are more expensive to set up. No more than 4 wind turbines could be raised;

- Implement solar panels, see Fig. 12. If the solar panels on a building generate more energy than the building consumes, overproduction is not rewarded;

- Apply thermal insulation, see Fig. 13.

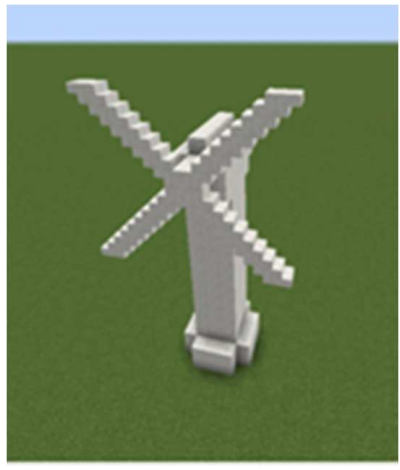

Figure 111 - Geocraft wind turbine

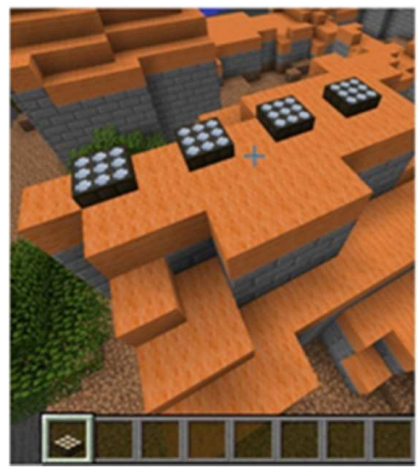

Figure 12 - Implementation of solar panels

During one lesson, the students could explore Geocraft. By removing and adding specific blocks, each design team could position solar panels, apply thermal insulation, or build wind turbines in their own Geocraft world. The next four lessons the students had to design a scenario to conserve as much energy as possible at the lowest costs in their virtual neighbourhood. Two times, the 
students were enabled to run a model in Geocraft calculating the inferred results with respect to costs and benefits.

This project raised the students awareness of the energy consumption of different buildings, as different types of buildings in Geocraft have different energy labels, conform reality. They got a substantiated understanding of the potential energy measures in their own neighbourhood. We succeeded in simplifying spatial energy models in a representative and functional way, so that 14 year old students with no experience in this field could use the models and understand not only what they were doing but also the causes of the result of their choices. The students got a deeper understanding of the principles of physics, because they could interactively play with different options and apply them in a familiar neighbourhood.

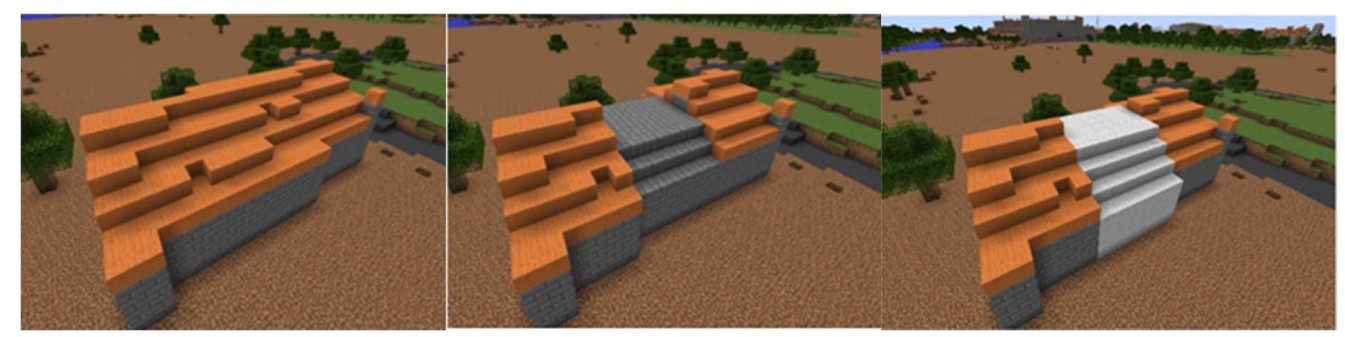

Figure 13 - Thermal insulation of a residence; first the outer layer is removed, then a white layer added

In addition, the students learned the meaning of a multi-criteria analysis. They got a feeling for the perspectives of different stakeholders; what is regarded to be the best solution totally depends on the chosen point of view. What is more important: a reduction of the costs of the consumer, a reduction of the costs of the energy supplier, $\mathrm{CO} 2$ reduction, or do you want to maximize sustainable energy production? During this project, the students had to tend different complex tasks to achieve a good result. They got a feeling how to address complex issues as a team and practised the required skills.

\subsubsection{Water management and land use Markermeer}

The Netherlands have a record of claiming land from water. For this purpose, between 1963 and 1976 a dike was raised between Enkhuizen and Lelystad, aimed at the creation of new land: the Markerwaard. However, over the decades agricultural production methods improved significantly, and in 2003 the Dutch government decided not to invest in new farmland anymore. Meanwhile, the waters in the closed off Markermeer area stagnate, resulting in a severely decreased water quality and heavily damaged ecosystem (Waterhout, Zonneveld and Louw, 2013).

The government decided to convert the area into an extensive nature reserve: a 'future proof ecological system'. In addition, the area should provide recreation space to accommodate the nearby densely populated urban areas. Furthermore, 
the opportunities to gain renewable energy and to raise freshwater food production should be explored. Potentially, the area is suitable to cultivate the Chinese mitten crab or usable algae. Sustainable energy might be generated by wind turbines, solar modules or by growing biomass (Gemeente Lelystad, 2015).

Over a 3 month period, the students worked on this project for 5 hours a week. Instead of 'an empty bathtub with stagnant water' the government aims for a variform area. The students had to design a spatial scenario to recover the damaged ecosystem and to optimize the combination of four objectives: recreation, food production, energy and most important: nature. After studying literature and gathering information from the internet, the students designed and eventually presented their solution in Geocraft, see Fig. 14.

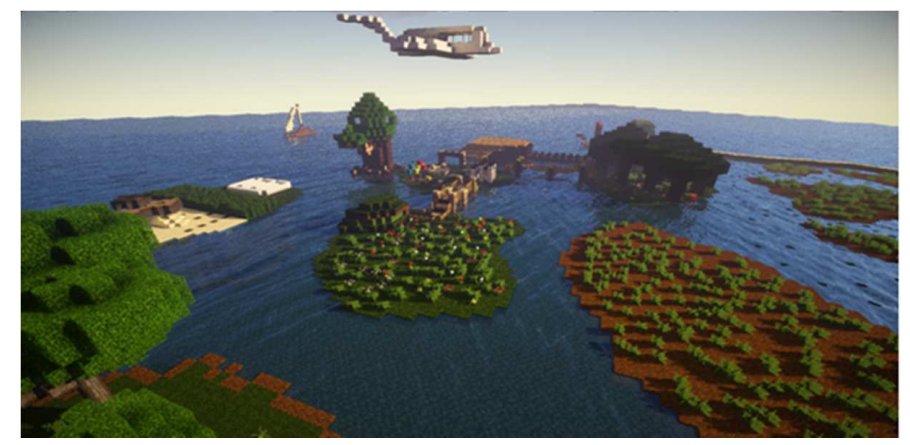

Figuru 14.1 - Winning spatial design for the Markermeer, made by high school students of the Technasium at Lelystad, $N L$. They optimized the combination of four objectives: recreation, food production, energy and most important: nature

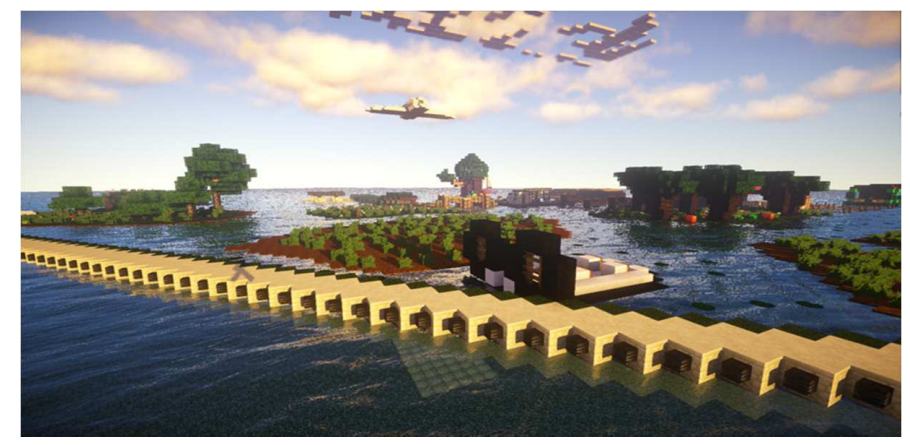

Figure 14.2 - The students designed a dike with a specific orientation in order to create a low energy shallow water area behind it, thus applying water management knowledge from experts

Hitherto in similar projects the students used photo collages, hand-made maps and scale models to present their solutions. The virtual visualisation of the designs improved them significantly: working in Geocraft effected a much higher level of detail and accuracy. However, this result was not the biggest gain: 
Geocraft improved the learning and design processes remarkably (Kelderman, 2016).

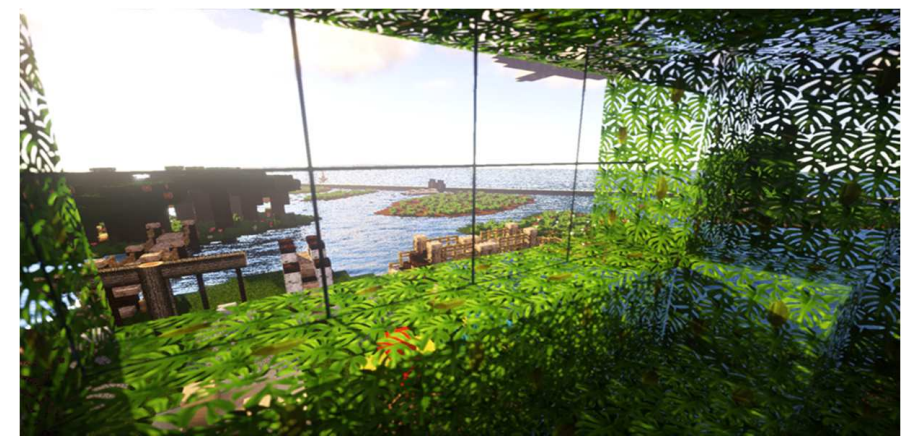

Figure 14.3 - The spatial design provides recreation spaces to accommodate the nearby densely populated urban areas

Geocraft provided an immersive experience. Instead of trying to understand the spatial relationships from descriptions and 2D maps, the students could walk around in the virtual representation of the studied area. Every spot could be approached and examined from every direction. Geocraft generated direct insight in scale size, dimensions and proportions. The students got an immediate look on the actual result while making changes; the impact of the changes revealed themselves at once. That made it a 'real experience' instead of a theoretical exercise.

Geocraft makes it very easy to modify the designs. This enables a 'sketching design process': students can try, modify, and renew their ideas without being confronted with considerable efforts coming along with making changes. As a result, the students obtained a higher creative freedom compared to 'the old way' of designing. Progressive insights could be accommodated much more easily.

Working in Geocraft advanced communication and collaboration processes within the design teams; working simultaneously in the same virtual environment necessitated tuning and adaption. Different subjects had to be amalgamated into a coherent joint design. Working isolated from one another was impossible, conflicting approaches revealed themselves at once. This provoked the substantiation of actions and decisions and coerced a more or less continuous exchange of substantive arguments. The students became much more aware of the impact of what they were planning to do. Problem solving thinking arose spontaneously; it was simply the only possible way to proceed. 


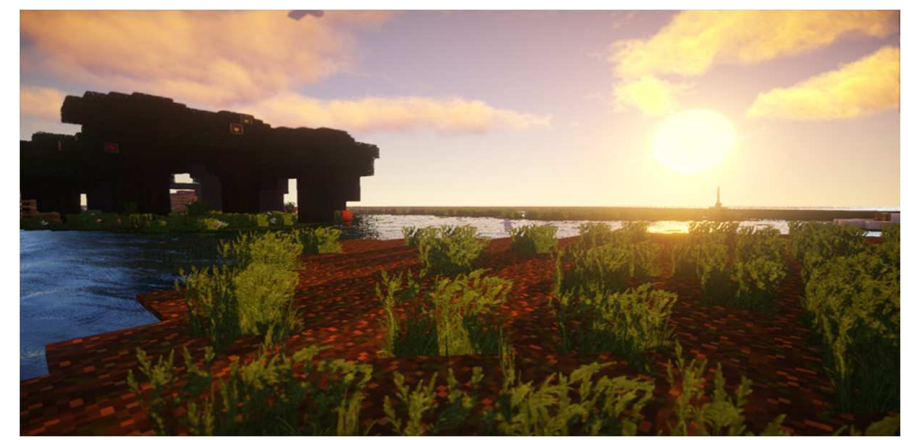

Figure 14.4 - Area for fresh water food production (Markermeer, spatial design by high school students of the Technasium at Lelystad, The Netherlands)

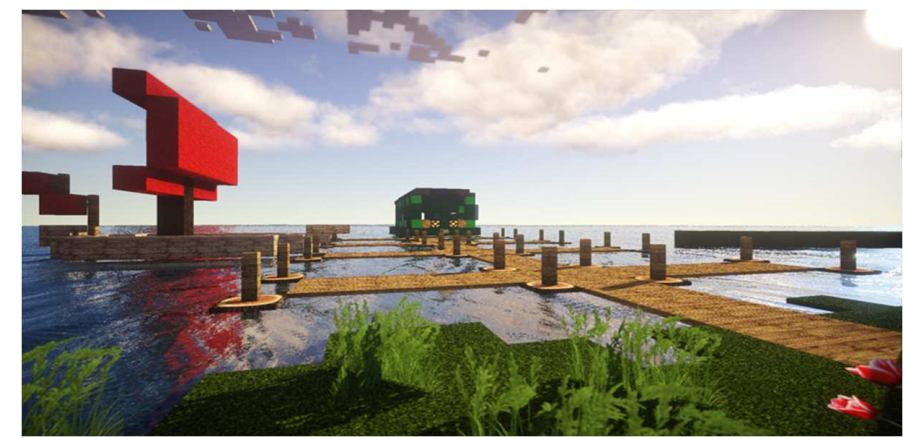

Figure 14.5 - Harbour area (Markermeer, spatial design by high school students of the Technasium at Lelystad, The Netherlands)

\section{DISCUSSION OF THE RESULTS}

Workshops in problem solving strategies might exhibit a poor learning transfer if carried out in more or less decontextualised training environments, which are insufficient related to real life (Kortmann, et al., 2016). To improve learning transfer, Herrington and Oliver (2000) have proposed so-called authentic learning environments (ALEs). ALEs are designed to enable learning experiences with real-world relevance. These use cases reveal that in Geocraft, we can simulate real world problems and raise real world strategies.

Please note that it is difficult to represent areas with large height differences.in Minecraft: the maximum height of a Minecraft world is 256 blocks or meters. There are plugins and technical measures to overcome some of the problems arising from the maximum height, like teleporting to a lower Minecraft altitude when entering a region with higher altitudes (the 'real' attitudes are translated to a lower Minecraft altitude). We did not have to deal with this, since in The Netherlands, there are no large heights differences. 


\subsection{Lessons learned from use case The Netherlands in Minecraft}

We achieved the three objectives of use case 1 (see Tab. 2):

- In Geocraft, the real world is simplified to blocks from 1 to 1 meter. Use case 1 revealed this is an appropriate level of abstraction to be able to effectively represent the real world, as illustrated by figures 4 and 6-9. Even round forms (see Fig. 15) or surfaces with an oblique orientation towards the north-south east-west grid (see Figure 4), can be adequately mimicked despite the jagged surfaces. People recognize their own neighbourhood immediately, different building styles are recognizable represented (see Fig. 4, 6-9, 15).

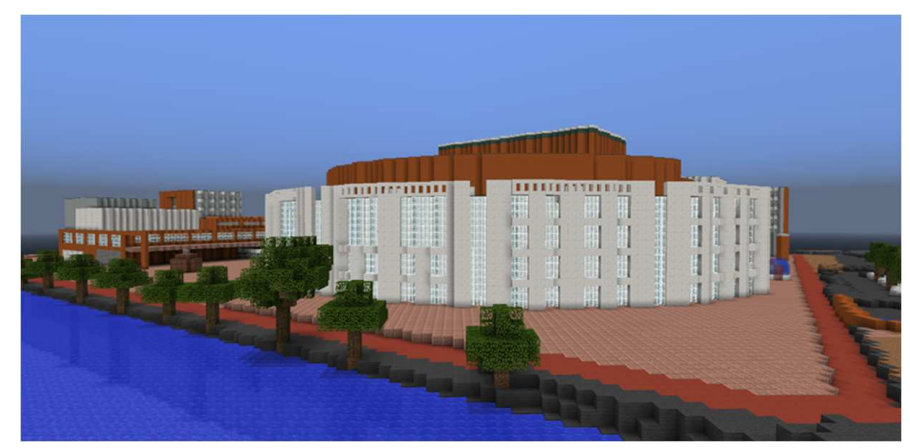

Figure 135 - Round buildings too, can be adequately build with the 1 to 1 meter blocks of Minecraft (The Stopera, Amsterdam, The Netherlands)

- Over 20,000 Minecraft players registered as GeoCitizen and worked on the Geocraft.NL server through the internet. So we proved Geocraft can support thousands of users via the internet; we infer Geocraft can effectively be offered to the public for public participation processes.

- We succeeded in creating and maintaining a Geocraft.NL community working on a common geospatial project. Thousands of children joined the geocraft.NL server to make The-Netherlands-in-Minecraft look as realistic as possible. After more than a year, the project is still going on. Collaboration and joint projects emerged spontaneously. However, if you just setup a server and offer free access to everybody without restrictions, it will be a complete mess in no time. The-Netherlands-in-Minecraft were practically destroyed at the day of release, another notorious example is the Danish server which was partly blown-up within a month from the release (Prigg, 2014). We learned several organisational aspects have to be implemented in order to create a maintainable and controllable Geocraft service. To maintain and control a Geocraft world several roles must be filled in: 
- The system administrator is responsible for supplying and upgrading the server hardware and backups, server user management, etc.

- The Minecraft server manager makes sure the Minecraft service software is up and running. He installs, updates and configures the necessary plug-ins. So basically he is responsible the functionality needed is available for the Minecraft players.

- In-game management keeps order and hands out claims.

Minecraft players are authenticated by services from Mojang. During a number of events and workshops, these services were down resulting in players not able to participate. It is possible to turn off this authentication for a Minecraft server. However this makes a Minecraft server extremely vulnerable to hackers as players can login with any username even that of an administrator. The authentication by the Mojang services is essential but availability is not guaranteed which could cause problems during events and workshops.

\subsection{Lessons learned from use case Zeeburgereiland}

The three objectives of use case Zeeburgereiland (see Table 2) are each met by a positive result:

- While designing the public space around their high school on Zeeburgereiland, non-Minecraft playing students learned on the job how to use this user friendly virtual building environment. Similar to LEGO bricks, all users intuitively understood how to use Geocraft blocks to adequately simulate reality and to easily design future scenarios.

- We demonstrated that spatial scenarios designed in Geocraft can be effectively translated into a feasible, practicable spatial design and be imported to the digital environment of a professional designer.

- The students recognized the planner's design as their own design and would definitely support its realisation. The design was presented to the stakeholders and part of the design is going to be realized indeed.

We infer that Geocraft can indeed be used to collect the ideas of citizens, in this case children, and engage them in a feasible way in urban planning issues to raise solutions that can reckon on public support. But we have to consider whether these results can be copied to the adult world. Adults did not train themselves so well in computer and gaming skills as the current generation children. And although there are adults playing Minecraft, many adults might not be attracted to use Minecraft. Especially adults without children playing Minecraft may be reluctant to participate in events or workshops involving Minecraft. This has to be investigated before we can conclude we can indeed effectively use Geocraft for citizen participation processes. Please note that the current children are the adults of the future. 
We also learned that the workshop needs to be very well introduced and facilitated; giving some freedom attracted students that were interested in Minecraft and not in planning the area and they were more destructive than constructive. In addition, the squared structure meant that the students tended to build in a north-south or east-west orientation, to have straight buildings. In principle, this might form a severe disadvantage when inviting non-professionals to make spatial designs in Geocraft. However, in the use case Markerwadden this tendency was not so clear.

\subsection{Lessons learned from use case Zaandam}

Use case Zaandam showed that Geocraft can operate as a smart environment wherein real-time impact models can be run to virtually simulate and visualise future developments and their implications, providing the user with relevant information during design processes. We learned that by serious gaming in Geocraft, in a limited amount of time the students acquired a deep understanding in a complex issue they were not familiar with before.

Using Geocraft in the classroom showed to be an effective method to motivate students to crack their brains and raise solutions for a complex issue. Their efforts resulted in concrete 3D GIS designs that can be imported, visualised and analyzed in other computer environments. These designs could be presented to the real stakeholders. It would be interesting to compare the plans of the stakeholders with those of the students, and analyse the similarities and the differences.

By working on this case study, the students fully understood the meaning of a multi-criteria analysis. We conclude Geocraft is a good method to raise mutual understanding and share ideas in a multi-stakeholder process. We agree with Lenferink, et al. (2016) that the combination of game theory and geodesign provides added value for planning support by facilitating a realistic discussion, and negotiation that is strongly connected to real-life locations, and by aiming at designing a common, collaborative solution. Next time we might explore what choices the students make if given a specific goal to aim for; we can, for example, divide the students into design teams, each representing another stakeholder with a different concern: the government, the people of the place, the energy supplier and the operator of the electricity grid.

\subsection{Lessons learned from use case Markermeer}

In this use case too, we achieved what we aimed for (see the objectives in Tab. 2). From use case Markermeer, we learned that using Geocraft the learning content was transmitted much more effectively than before, because Geocraft provided an immersive experience (Kelderman, 2016). Moreover, Geocraft turned out to be a great tool to induce the typical $21^{\text {th }}$ century skills (Trilling and Fadel, 2012) necessary to successfully complete the task: communicating, finding and evaluating information, creating and innovating, collaborating, and 
problem solving. The students successfully incorporated insights of experts into their designs.

Working in Geocraft advanced communication and collaboration processes within the design teams. Moreover, this approach maximized the engagement of the students. Not only because they became much more aware of what they were doing, but also because they had great fun 'playing with Minecraft'. The supervising teacher takes the view that the results of the students improved significantly by using Geocraft (Kelderman, 2016). The next step is working with control groups to demonstrate that these improvements are statistically significant.

During this project, we became very aware of being dependant on good internet connections. Sometimes, the servers were down or somehow the internet connection failed, which made it impossible to proceed and to optimally use the dedicated education time. Moreover the technical support of the project has a price, as long as the necessary computer and internet facilities are not standard available. Another disadvantage of working in Geocraft, was that teachers found it more difficult to give guidance to the project and to discuss the mid-way results. Maybe this is inherent in working in a virtual world; on the other hand we do not know yet whether teachers simply have to get used to another way of judging and supervising. We have to execute more projects to be able to judge this.

\section{POSSIBLE FURTHER APPLICATIONS}

As an easy to use visualisation tool, Geocraft can be used as a strong communication tool to display and share ideas and plans. Geocraft can enable citizens to virtually concretize their ideas on for example urban planning or future land use. Geocraft can offer citizens the opportunity to communicate their ideas on geospatial issues towards authorities in an effective way and vice versa: governments can offer citizens the opportunity to virtually visit and examine future scenarios. Either through the internet in virtual reality or in situ by augmented reality (AR).

\subsection{Augmented Reality and 3D sensors as a collaborative tool}

The combination of AR, georeferenced 3D virtual worlds such as Geocraft and high precision satellite positioning such as Real Time Kinematic GPS (Mekik and Arslanoglu, 2009) or Precise Point Positioning (Bisnath and Gao, 2007) technology enables a host of new experiences. The real world can now be blended with the virtual world. Invisible aspects of the concrete world can be observed using a dedicated (georeferenced) virtual world as an overlay on top of the real world. These virtual overlays can contain all kinds of available geospatial data, for example sensor data on current phenomena such as heat distribution, concentrations of atmospheric particulate matter or chemical pollution levels. Not 
only real time data can be visualized, but also predicted and modelled data (Geodan Research, 2016a).

With AR, these visualisations can be experienced in-situ - being at the actual location. That means otherwise invisible phenomena and future changes can be examined while considering the real, physical context. We envision this will raise insights in complex situations. These visualisations are not static views, as AR allows for hiding portions of reality and projects future plans as if they unfold on the spot at that very moment. With transparent AR glasses such as the Microsoft Hololens (Geodan Research, 2016b), discussing these plans with other AR glass users becomes natural as normal eye contact is preserved. Normal navigation such as walking around remains possible as the user is still grounded in reality, greatly enhancing the experience. These possibilities might provide a next step towards a synergetic multidisciplinary approach, effectively exchanging data and insights across the limits of disciplines.

\subsection{Gaming gets really serious}

Via the internet, children play all sorts of games in Minecraft. For example 'conquer the flag': two teams of children each build the best defence structure they can imagine, in only 5 minutes time. Then the battle begins. The team with the best defence structure, the best battle strategy and the best cooperation wins. Geocraft is a smart environment in which we can simulate the real world and raise real strategies and solutions for real problems. For example the battle against sea level rise, air pollution or noise disturbance. Teams can get a budget and an aim to strive for, and implement different options to achieve that aim, like we illustrated in use case Zaandam. Impact models can instantly supply information on the results of the used interventions. The team solving the problem with the best result against the lowest costs wins.

We envision serious gaming in Geocraft can help to reach optimal solutions for tomorrows problems. Game mechanics can effectively influence human behaviour towards cooperation, higher effectiveness and creativity (McGonigal, 2011; Van Boven and Fennema, 2014). We want to explore whether game mechanics can contribute to build a system of smart governance.

\section{CONCLUSION}

Geocraft provides an excellent interactive virtual 3D environment at a wellchosen level of abstraction to visualise, design and explore future scenarios, raising spatial insight and mutual understanding. It is a user friendly tool to facilitate effective participation and engagement of citizens, youth in particular (see for example use case 'The Netherlands in Minecraft'). As such, it can be a powerful tool to support collaborative decision making (see for example use case Zeeburgereiland). 
From the discussion of the results, we conclude that we presented clear evidence for the added value of Geocraft for education on geospatial issues. Geocraft advanced learning and design processes, and improved communication and collaboration (see all use cases). We infer that Geocraft is a very strong educational tool to raise awareness and insights in complex issues with a geospatial component (see for example use cases 'Zaandam' and 'Markermeer'). However, the statistical proof of the learning improvements still has to be delivered (forthcoming).

We think the use of Geocraft can contribute to a better urban future by facilitating the creation of high level solutions. Through internet interfaces, all urban actors can get a voice and communicate their insights and ideas. Geocraft could be a way for citizens' participation in spatial development and inspire them to take ownership of the city they inhabit.

\section{ACKNOWLEDGMENTS}

The research of Sanne Hettinga on Public Participatory GIS is part of the research programme 3D4EM, which is supported by the Dutch Technology Foundation (STW), which is part of the Netherlands Organisation for Scientific Research (NWO), and which is partly funded by the Ministry of Economic Affairs. We thank RijksWaterstaat, part of the Ministry of Infrastructure, for supporting the Ph.D. Research of Mark Opmeer on the use of GIS in education (Raamkontrakt VU-RWS). We would like to thank Hans Leeflang, landscape architect and Chairman of the Year of Spatial Planning, for his continuous support of our GeoCraft project. We are most obliged to the high schools involved, their teachers and students. We thank the employees of Geodan and SPINlab for their enthusiasm and committed efforts to achieve the results presented in this paper. Finally we would like to thank the employees and volunteers of GeoFort for developing the GeoCraftNL community, in particular Koen Lemmen, software developer at GeoFort.

\section{REFERENCES}

Bisnath, S. and Gao, Y., 2009. Current State of Precise Point Positioning and Future Prospects and Limitations. In: M.G. Sideris, eds. 2009. Observing our Changing Earth. International Association of Geodesy Symposia 133. Springer: Berlin Heidelberg. pp 615-623.

Boonstra, B., 2015. Planning Strategies in an Age of Active Citizenship - A Poststructuralist Agenda for Self-organization in Spatial Planning. Ph.D. Utrecht University.

Bregt, A., Crompvoets, J., Scholten, H.J. and Van de Crommert, P., 2005. Die Niederländische Nationale Geodateninfrastruktur - Ruckblick, Gegewart und Zukunft. In: L. Bernard, J. Fitzke and R.M. Wagner, eds. 2005. 
Geodateninfrastruktur: Grundlagen and Anwendungen. Heidelberg: Wichmann Verlag. pp.29-35.

Buurtperspectief, 2015a. Minecraft as a planning tool - part 1 - The environment we dream of. [video online] Available at: $<$ https://www.youtube.com/watch?v=P1yKWedHS20> [Accessed 7 November 2016].

Buurtperspectief, 2015b. Minecraft as a planning tool - part 2 - A more realistic design. [video online] Available at: $<$ https://www.youtube.com/watch?v=zIsEfBAX114> [Accessed 7 November 2016].

De Kleijn, M.T.M., Van Manen, N., Kolen, J.C.A. and Scholten, H.J., 2014. Towards a User-centric SDI Framework for Historical and Heritage European Landscape Research. International Journal of Spatial Data Infrastructures Research, 9, pp.1-35.

Dias, E., 2016. Wind Planning using GIS, game engine and sound modelling. [video online] Available at: <https://www.youtube.com/watch?v=_5hsplPCFlc $>$ [Accessed 6 September 2016].

European Union, 2009. Directive 2009/28/EC of the European Parliament and of the Council of 23 April 2009 on the promotion of the use of energy from renewable sources and amending and subsequently repealing Directives 2001/77/EC and 2003/30/EC. [online] Available at: <http://eurlex.europa.eu/legal-content/EN/TXT/?uri=URISERV\%3Aen0009> [Accessed 7 November 2016].

Foley, J.D., Van Dam, A., Hughes, J.H. and Feiner, S.K., 1990. Computer Graphics: Principles and Practice. $2^{\text {nd }}$ ed. Boston: Addison-Wesley Longman Publishing Co.

Gemeente Lelystad, 2015. Bestemmingsplan Marker Wadden. [Online] Available at: <http://www.ruimtelijkeplannen.nl/documents/NL.IMRO.0995.BP00046VG01/t_NL.IMRO.0995.BP00046-VG01.html> [Accessed 22 November 2015].

GeoCraft.NL, 2016a. What is GeoCraftNL. [video online] Available at: $<$ https://m.youtube.com/watch? $=$ KK2uuVMsuHs $>$ [Accessed 9 November 2016].

GeoCraft.NL, 2016b. Project GeoCraft NL - Commissarissen van de Koning. [video online] Available at: $<$ https://www.youtube.com/watch?v=bU3nZGHmwEw $>$ [Accessed 9 November 2016].

GeoCraft.NL, 2016c. Heel Nederland in Minecraft! - GeoCraft Impressie. [video online] Available at: <https://www.youtube.com/watch?v=Bi1s4h12gBc> [Accessed 9 November 2016]. 
Geodan Research, 2016a. AI Crowd Simulation Demo. [video online] Available at: $\quad<$ http://research.geodan.nl/sites/GeodanAI/CrowdSim/> [Accessed 2 December 2016].

Geodan Research, 2016b. Geocraft on the Hololens. [video online] Available at: $<$ https://www.youtube.com/watch? $=$ XWgbMgKBa5I\&feature=youtu.be $>$ [Accessed 2 December 2016].

Herrington, J. and Oliver, R., 2000. An instructional design framework for authenthic learning environments. Educational technology research and development, 48(3), pp.23-48.

Kearney, K., 2015. Create and construct: incredible Minecraft Cities. London: Octopus Publishing Group Limited.

Kelderman, O., 2016. Reflectie Markerwaddenproject en het werken met Minecraft Edu. [e-mail] (Personal communication, 14 February 2016).

Koomen, E., Stilwell, J., Bakema, A. eds, 2007. Modelling Land-Use Change: Progress and Applications. Dordrecht: Springer Science+Business Media B.V.

Kortmann, R., Bekebrede, G., Van Daalen, E., Harteveld, C., Mayer, I. and Van Dierendonck, D., 2013. Veerkracht - a game for servant-leadership development. In: C. Otoiu and G. Otoiu, eds. 2013. The journey of change: mapping the process. Cluj-Napoca: Editura ASCR. pp.129-152.

Kourtit, K., Nijkamp, P. and Scholten, H.J., 2015. Editorial: Urban Futures. Applied Spatial Analysis and Policy, 8(3), pp.177-179.

Lazaroiu, G.C. and Roscia, M., 2012. Definition methodology for the smart cities model. Energy, 47(1), pp.326-332.

Lee, D.J., Dias, E., Scholten, H.J. eds., 2014. Geodesign by Integrating Design and Geospatial Sciences. The GeoJournal Library vol. 111. Cham (ZG): Springer International Publishing.

Lenferink, S., Arciniegas, G., Samsura, A. and Carton, L., 2016. Integrating Geodesign and game experiments for negotiating urban development. Research in Urbanism Series, vol.4: Geo-Design. Advances in bridging geo-information technology, urban planning and landscape architecture, pp.71-92.

McGonigal, J., 2011. Reality is broken - Why games make us better and how they can change the world. London: The Penguin Press.

Mekik, C. and Arslanoglu, M., 2009. Investigation on Accuracies of Real Time Kinematic GPS for GIS Applications. Remote Sensing, 1(1), pp.22-35.

Pakhuis de Zwijger, 2016. Zeeburgereiland - In gesprek met bewoners, ondernemers en stadmakers over de toekomst van het eiland. [online] Available at: $\quad<$ https://dezwijger.nl/programmareeks/zeeburgereiland $>$ [Accessed 7 November 2016]. 
Prigg, M., 2014. American hackers 'bomb' Minecraft version of Denmark and raise stars and stripes in cyber-attack. MailOnline Science \& Tech, [online] 8 May 2014. Available at: <http://www.dailymail.co.uk/sciencetech/article2623697/American-hackers-bomb-Minecraft-version-Denmark-raise-starsstripes-cyber-attack-education-project.html $>$ [Accessed 23 February 2016].

Rafiee, A., Van der Male, P., Dias, E. and Scholten, H., (forthcoming). Wind Turbine Planning Platform: Integration of Game Engine-GIS-Sound Model Triplet. Environmental Modelling \& Software. (Submitted for publication February 2016).

Sociaal-Economische Raad (SER), 2013. Energie akkoord voor duurzame groei. Den Haag: Sociaal-Economische Raad.

Steinitz, C., 2012. A Framework for Geodesign: Changing Geography by Design. Redlands: Esri Press.

Stillwell, J.C.H. and Scholten, H.J. eds., 2001. Land use simulation for Europe. Dordrecht: Kluwer Academic Publishers.

Trilling, B. and Fadel, C., 2012. 21st Century Skills - Learning for Life in Our Times. Hoboken: John Wiley \& Sons Inc.

TwinQ, 2015. Top 10 games van kinderen en jongeren in 2014 - Minecraft en FIFA meest populair. Twinq, [online] 14 January 2015. Available at: $<$ http://www.twinq.nu/top-10-games-van-kinderen-en-jongeren-2014-minecraften-fifa-meest-populair/> [Accessed 24 November 2016].

Van Boven, H. and Fennema, E., 2014. @Hearts @Minds \# Transreality Achieving better outcomes by playing reality in a Natural Meta Game. Rotterdam: Transreality.com.

Van der Schee, J. and Scholten, H., 2009. Geographical Inforation Systems and Geography Teaching. In: J. Scholten, R. Van de Velde and N. Van Manen, eds. 2009. Geospatial Technology and the Role of Location in Science. The GeoJournal Library vol. 96. Cham (ZG): Springer International Publishing. pp.287-301.

Van der Zee, E. and Scholten, H.J., 2014. Spatial Dimensions of Big Data: Application of Geographical Concepts and Spatial Technology to the Internet of Things. In: N. Bessis, C. and Dobre, C., eds. 2014. Big Data and Internet of Things: A Roadmap for Smart Environments. Studies in Computational Intelligence. Cham (ZG): Springer International Publishing. pp.137-168.

Waterhout, B., Zonneveld, W. and Louw, E., 2013. Case Study Markermeer IJmeer, the Netherlands: Emerging Contextualisation and Governance Complexity. CONTEXT Report 5. Amsterdam: AISSR programme group Urban Planning. 
Wikipedia, 2016. List of best-selling video games. [online] Available at: $<$ https://en.wikipedia.org/wiki/List_of_best-selling_video_games> [Accessed 24 November 2016].

World Urban Campaign partners, 2012. Manifesto for Cities. [pdf] Kenya: UNHabitat. Available at: $<$ http://mirror.unhabitat.org/images/WUC_Manifestos/Manifesto\%20For\%20Citi es_English.pdf $>$ [Accessed 15 March 2016].

World Urban Campaign partners, 2016. The City we need 1.0. [pdf] Available at: $<$ http://www.worldurbancampaign.org/city-we-need $>$. Kenya: UN-Habitat [Accessed 15 March 2016].

\section{ABOUT AUTHORS}

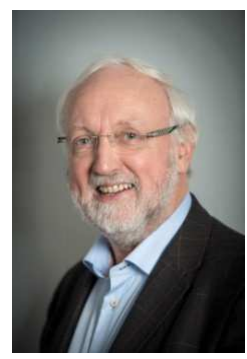

Henk Scholten (henk@geodan.nl) is professor in Spatial Informatics at the Faculty of Economics of the Vrije Universiteit Amsterdam and Director of the Spatial Information Laboratory. With Evert Meijer, he founded Geodan, one of the largest European companies specialised in Geospatial Information Technology. For his significant contribution to advancing the science and technology of GIS, Henk Scholten was honoured with a Dutch Royal Award (2005), the ESRI Lifetime Achievement Award (2009), the title of honorary Doctor of Science from the Manchester University (2015) and the Geospatial World Leadership Lifetime Achievement Award (2016).

Eduardo Dias, Sanne Hettinga, Mark Opmeer and Niels van Manen perform research at the Spatial Information Laboratory (SPINlab), Vrije Universiteit Amsterdam, Faculty of Economics and Business Administration, De Boelelaan 1105, 1081 HV Amsterdam, The Netherlands, +31 $20 \quad 59$ 86099, spinlab.feweb@vu.nl, http://spinlab.vu.nl

Steven Fruijtier, Marianne Linde, Rubio Vaughan, Steven Bos, Heidy van Kaam and Ceciel Fruijtier work for the Research Department of Geodan, President Kennedylaan 1, 1079 MB Amsterdam, The Netherlands, +31(0)20 - 5711 311, info@geodan.nl, http://www.geodan.com

Willemijn Simon van Leeuwen is founder and director of the GeoFort, Nieuwe Steeg 74, 4171KG Herwijnen, The Netherlands, +31 (0)345 - 630 480, info@geofort.nl, http://www.geofort.nl. In 2016, GeoFort was awarded by the European Museum Academy and Hands On, the international association of children in museums, as the best childrens museum of Europe.

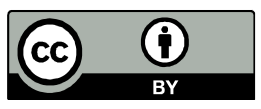

